Virginio Marzocchi. Full Professor of Social and Political Philosophy at the Dipartimento di Filosofia (Università degli Studi di Roma "La Sapienza"). In the light of the twentieth-century linguistic turn, his interests lie in: Theory of Society; Theory of State and criticaldeliberative Democracy; Legal Theory. He is Editor-in-chief of the journal Politica \& Società (il Mulino) and has published the following books: Per un'etica pubblica. Giustificare la democrazia (Liguori, 2000), Ragione come discorso pubblico. La trasformazione della filosofia di K.-O. Apel (Liguori, 2001), Le ragioni dei diritti umani (Liguori, 2004), Filosofia politica (Laterza, 2011).

Contact: virginio.marzocchi@uniroma1.it 


\section{DOES POWER UNIFY A SOCIETY?}

DOI: $10.17450 / 150202$

Virginio Marzocchi

Università degli Studi di Roma, "La Sapienza"

Reception date $29^{\text {th }}$ September 2015; acceptance date $25^{\text {th }}$ October 2015. This article is the result of research activities held at the Dipartimento di Filosofia, Università degli Studi di Roma "La Sapienza".

\section{Abstract}

After an introductory consideration on the specificity of philosophy and social philosophy about the socio-historical world, which can no longer be summarized under the name of "politics", the essay advances a concept of society not as a unity of individuals, territorially or culturally secluded, but as a network of linguistic games, institutions and differentiated spheres. The result is a concept of power constitutively in the plural, which is thought as primarily organizing and collective. The main question, which is only extrinsically negotiable in terms of justice, results in the problem of how to avoid that a sphere predominates over the remaining ones, thus compressing the contributions, potentialities and inclusive capacity of each one.

\section{Keywords}

Social Philosophy, powers, social differentiation, Philosophy of Language.

\section{Resumen}

Tras considerar la especificidad de la filosofía y de la filosofía social con respecto al mundo histórico-social, que ya no se puede definir bajo el término "política", el artículo propone un concepto de sociedad no como conjunto de individuos desde un punto de vista territorial o cultural, sino como red de juegos, instituciones o ámbitos diferenciados. De ahí procede un concepto de poder constitutivamente al plural, considerado 
antes que todo como organizante y colectivo. El eje principal -que solo extrínsecamente se puede solucionar en términos de justicia- atañe al problema de cómo evitar que un ámbito subyugue a los demás, llegando a reprimir las contribuciones, las potencialidades y capacidades inclusivas de cada uno de ellos.

\section{Palabras clave}

Filosofía social, poderes, diferenciación social, filosofía del lenguaje.

This contribution starts off by questioning the second term of the title, "society", to clarify the first "power" from a point of view that I consider philosophical, or, more exactly, socio-philosophical.

1. I would like to begin with a short initial consideration on the philosophical-social perspective, as I understand and propound it.

Philosophy is characterized by an "inactive" reflection on the meaning of material signs in use (i.e. spoken or written words) through other words within a dialogical-argumentative context. In its being inactive, programmatically and more radically than other types of knowledge, which are also linguistically articulated, proposed and defended, philosophy separates inter-locution from its constitutive and original interlacement with inter-action To articulate such an interlacement (Verwobenheit), typical of everyday language, L. Wittgenstein has coined, in his Philosophische Untersuchungen, the expression Sprachspiele or language games, where words, thanks to their ability to achieve certain works/results through a successful coordination of interaction, assume identity of meaning for more speakers/interactors and constancy of meaning over time for a single speaker/interactor ${ }^{1}$. Compared to philosophy, which I consider as a specific and original invention characterizing the West and therefore I clearly distinguish from other cultural turns or conquests in different parts of the geo-historical world ${ }^{2}$, other types of knowledge proved and prove much less radical

1. For an interpretation of language games, and of the irreplaceable contribution of the second Wittgenstein to the twentieth century linguistic turn in general, in the sense here only mentioned, see V. Marzocchi, Le ragioni dei diritti umani, Liguori, Napoli, 2004, pp. 122-129.

2. I move away from the historical-evolutionary theory of so-called Axial Age (first advanced by K. Jaspers in his Vom Ursprung und Ziel der Geschichte of 1949, who coined the term "Achsenzeit"), in particular in the way it is developed by R.N. Bellah, especially in Religion in Human Evolution: From the Paleolithic to the Axial Age (The Belknap Press of Harvard Univ. Press, Cambridge/MA, 2011), and reassessed by J. Habermas also in his last collection of essays Nachmetaphysisches Denken II (Suhrkamp, Berlin, 2012). For a recent and revised discussion of this theory see R.N. Bellah, H. Johas (eds.), The Axial Age and its Consequences, The Belknap Press of Harvard Univ. Press, Cambridge/MA, 2012 (where I recommend the 
in rendering inter-locution theme, medium and place of problematization/confirmation of their proposals. So, for example, religion does not give up community rites; natural sciences produce interventions in the world and have recourse to experiments for their corroboration; arts assert themselves by creating works (which, although sometimes only literary, rely on the materiality of the linguistic sign).

In other words, philosophy momentarily, and in a problematizing perspective, interrupts the daily communication that functions through speech acts ${ }^{3}$, which speakers/ interactors generally accept either because of the ability of the above-mentioned speech acts to produce effective, satisfactory interactions, insofar they lack practicable alternatives, or on the basis of the authority/power of those who perform them.

I would advance the hypothesis that this reflexive focus on inter-locution through the problematizing re-use of inter-locution itself was invented and affirmed within a partially democratic context, or also in reaction to it, that is, where adult males were thought/supposed to be:

1. authors responsible of their own actions as to the origin of the latter (as they were not exclusively determined by indomitable inner impulses or by external influences) and in their consequences (as they were not dependent by an unstoppable destiny or by the will of other and superior powers);

2. able to plan the politèia or basic structure of their society (pòlis) and therefore to govern it on the basis of a public debate and of a comparison between the proposals and knowledges that could be elaborated, achieved and tested by them.

The focus on the linguistic medium, more and more illuminated in its multiple dimensions (semantics, syntactic and pragmatic) , $^{4}$ as well as considered in its variety over time and from place to place, led or should lead philosophy to two remarkable results.

\footnotetext{
essays, both highly critical, by J. Casanova and J. Assmann); n. 2/2015 of Politica \& Società, devoted to L'età assiale: religione, politica, storia.

3. I am referring here to the interpretation of speech acts offered by J. Habermas and especially K.-O. Apel, beyond the way they were first highlighted by J.L. Austin and J. Searle and beyond the following revisions made by Searle himself (from Intentionality, Cambridge Univ. Press, Cambridge, 1983, to "How Performatives Work" (1989), in Id., Consciousness and Language, Cambridge Univ. Press, Cambridge, 2002, pp. 156-179). Apel in particular has forcefully defended not only the irreducibility of the dual structure of the performative and propositional Sprechhandlungen or Sprechakte, but he has also correctly seen that these latter are not always proposed or adopted in light of the validity claims raised in the performative component (as I observe in the text). In this regard and principally for a completion of Wittgenstein's language games theory by the speech acts theory see K.-O. Apel, "Die Logosauszeichnung der menschlichen Sprache. Die philosophische Tragweite der Sprechakttheorie”, in H.-G. Bosshardt (ed.), Perspektiven auf Sprache. Interdisziplinäre Beiträge zum Gedenken an Hans Hörmann, de Gruyter, Berlin-New York, 1986, pp. 45-87; V. Marzocchi, Le ragioni dei diritti umani, pp. 131-140. 4. In this regard see K.-O. Apel, "Vorwort”, in Id., Paradigmen der Ersten Philosophie, Suhrkamp, Berlin, 2011.
} 
1. To a distinction (at least in the sense of a never complete reducibility of the one to the other) between the human, on the one hand, and the natural on the other hand. The human world is internally constructed by propositional-inferential meanings and connections, which are used, shared, elaborated, revisable and testable by speakers/ knowers/agents, so that it might be understandable, or better reconstructable, by a third person, who at least initially teases out those meanings and connections from a participant point of view (or better from the point of view of co-speaker and potential inter-agent). The natural world is instead constituted or drawn/categorized by applying to it some propositional-inferential meanings and connections not used/understood by entities of the natural world, but it is constituted by meanings which are shared and tested by and among speakers/knowers/agents through a perceptual-cognitive-manipulative exchange (that is not linguistic-communicative or interactive) with the entities of the natural world 5 .

2. To replace the one, universal and transcendental subject, that constitutes the world, with an inter-subjectivity of communications and interactions, through which the human world can be characterized in itself, and not only in contrast to the natural world: both (a.) as intrinsically social, in the sense that individual subjectivities appear as moulded by the relations where they are situated and that shape their spontaneity/singularity and structure it, but the resistance of such relations, as always mediated/built by a reflexively employable language thanks to the irreducible performative component of speech acts within a language game, at the same time seems to depend on the acceptance/sharing by speakers/interactors; and (b.) as historical, not only in the sense of variable in its routes and developments from place to place, but especially in the sense of a continuity, which is independent from the varying of individuals and succession of generations, without which there is no history, even in the face of far-reaching transformations, innovations, acquisitions (some of which, once emerged, have no longer been abandoned and have spread universally, as for instance writing or money or even technical tools ${ }^{6}$ ).

Social philosophy is interested in this socio-historical world. It chooses such qualification, actually rather recent and much less classic than the qualification of "political", when one realizes that "political" at least here in the West, unlike classical Greek world, has become increasingly circumscribed, i.e. a sphere among spheres, in the form of public-state vis-à-vis a more comprehensive and diversified social.

5. For a more accurate and justified distinction between "human world" (socio-historical) and "natural world" see V. Marzocchi, "Parola e mondo storico-sociale: il caso del diritto", in Politica \& Società, 1, 2012, pp. 89-112.

6. See for example T. Parsons, "Evolutionary Universals in Society", in American Sociological Review, 29, 1964, pp. 339-357; N. Luhmann, Die Gesellschaft der Gesellschaft, Suhrkamp, Frankfurt/M, 1998, pp. 505-506. 
However, because of the geo-temporal multiplicity and variety of the above-mentioned socio-historical world, it is difficult to see clearly how the project of a social philosophy, beyond a further but rather generic invitation to interdisciplinarity, could contribute to knowledge empirically accumulated by more or less young disciplines (in comparison to the philosophy) such as historiography, sociology, anthropology, psychology, aesthetics, as well as other and more specific, such as, for example, theology or religious sciences, economy, jurisprudence, history of sciences and so on. Obviously I could refer to glorious and now classical antecedents ascribable to the canon or tradition of social philosophy at least since Rousseau up to Castoriadis or to the Frankfurt School, which has expressly claimed such denomination also on the part of its more recent exponents.

I prefer a more theoretical answer. Or better, I think that, beyond a reflection on methods and conditions of verifiability/criticability of such disciplines and besides a genealogical excavation as to they have arisen, sectorized and affirmed themselves, the first task of social philosophy is a critical examination of the fundamental and central concepts (words) in relation to their consistency/validity and the theoretical presuppositions/consequences that their acceptance and use involve, also because of the "inactivity" I have initially employed to characterize philosophy tout court. In my opinion, social philosophy can be reduced neither to a genealogy of discourses nor to a history of ideas or Begriffsgeschichte, but, just as philosophy, it stays aware of the interpretative-constructive and hypothetical-inferential character of our words/concepts and of the fact that they arise and stabilize in working practices and institutions, contexts and differentiated spheres, about which, through comparison among their various empirical-disciplinary reconstructions, social philosophy tries to test the adequacy of discourses/ concepts, in order to frame them as successful or unsuccessful/insufficient/regressive learning processes stimulated by unexpected challenges/emergencies. This way social philosophy avoids an inner history of the spirit or the perspective of following and superior stages of evolution for only one possible route, in its turn predisposed by an inner logic or depending on a primordial origin.

I will try to test the philosophical-social view now sketched through a discussion of the concept of society and then the concept of power related to the first.

2. To begin with, I would like to contest the idea that the socio-historical world is constituted by many societies, each of them conceived as a unit, or rather, having a central core, whose creation or change would constitute/transform the social whole 
(a society), as modelled by that core: whether this core has an ideal-cultural nature (as, for instance, a particular Weltbild or Lebenswelt or sacral complex or language) or whether it has a local-material nature, connected with determinate geographical boundaries (such as a relative monopoly of force by a centre/vertex, the mode of production, orderings which can be imposed through coercion or more in general through resources that can be extracted in a given area).

I believe such a conception of societies proves largely pre-conditioned by a certain way in which the reflection that we call politics has set out, affirmed and then transformed itself; already in classical Greece (as the name itself suggests), politics concerned the whole horizon of what today we call social. The polis, or better the many pòleis are thought as self-sufficient (independent) wholes, whose underlying structure (constitution/politèia), if correct or right, has to make sure that every part can play a role appropriate to it (Plato), or also that no one prevails for its own advantage on the others, thus disregarding its own nature as a part of the whole. That is, every part should collaborate, as much as its nature and its position allow, to the determination and to the pursuit of what would be later designated as bonum commune, thus translating the Aristotelian to koinòn symphèron.

Although in his definition of the res publica Cicero considers consociation not only for "utilitatis communione" but also for "iuris consensu", so signalling the rise of a politically autonomous sphere, that is, the ius, and although subsequently it will be considered the existence of variegated communitates that not only intersect with each other at the local level but also have different ends, among which the two perfectae (civitas and ecclesia ${ }^{8}$ ) in particular. However, the main stream of modern political thought, also replacing the idea of "government" (archè, àrchein) with that of "power", of an imperative sovereign power, will see as essential, to guarantee collective peace or freedom of the individual (subject or citizen), the establishment of a single political-social body (or better, of many social political bodies, territorially secluded and formed by individuals living on such territory), whose centre/vertex could probably and through uniform rules intervene on all the aspects and dimensions of one's life or, at least, on all the external behaviours that can be responsibly performed by the individual, as seems to have occurred with the rise of the system of national-constitutional States ${ }^{9}$ since the end of the eighteenth century.

$\overline{\text { 7. Cicero, De Rep., I } 25 .}$

8. Aquinas, Sum. Theol. I-II q. 98 art. 1 respondeo.

9. With the expression "system of States" I mean the theory of states formation and the construction of their mutual and rival sovereignty, as developed by C. Tilly, Coercion, Capital and European States, AD 990-1990, Basil Blackwell, Cambridge/ MA, 1990; see also Id. (ed.), The Formation of National States in Western Europe, Princeton University Press, Princeton, 
Liberally taking a cue from N. Luhmann ${ }^{10}$, I would make the contention that the greatest limit or misleading presupposition of such an endogenous and at once top-centralistic formulation of society lies in the conviction that societies are comprised of human beings, who are claimed to represent their ultimate constituents and have to be put in relation with each other within stable groups/communities ${ }^{11}$. Nor is it any better, in my opinion, to replace the term "human being", provided with certain characteristics or needs, with the more flexible and modern term "subject", characterized by both a creative/unforeseeable spontaneity/singularity and an adaptive plasticity, marked by a constitutive lack or necessity ${ }^{12}$. I do not intend to devalue outright the term "subject", which is useful insofar as it gives an account both of innovating answers and of a critical-reflexive ability, which my own discussion obviously presupposes. Yet I think that in both cases, if the basic unit is the "human being" or the "subject", then it will proceed in the sense of determining/circumscribing societies on the basis of people's (exclusive or at least prevailing) belonging to one of them. Although those forms of belonging are not as established and specified as are forms of belonging based on state subjection or citizenship, they presuppose and require a certain personal identity or similar features in terms of lifestyles, habits, rules, expectations of behaviour, mentality among members; i.e. an identity of single individuals fixed in structures of personality, which has to prevail over the differences and that, necessarily, can include only those who manage to have certain characteristics, while it excludes those who fail to acquire them. This all the more when a society, as often said, individualizes itself in life paths apparently autonomous and independent from the origin of the individuals.

I do not mean here to deny entirely the homologizing and naturalizing tendency of the social (in light of which the absence or omission of certain behaviours or capabilities comes to take the shape of humanly unnatural or against-nature); but at the same time I do not mean to embrace this view of belonging/identity and then to define this tendency as an inevitable destiny of the social, which, indeed from my personal point of view, takes the shape of the socio-historical and then turns out to be productive of

1975. For the periodization of the different State-forms I make use, though quite liberally, of M. Fioravanti (ed.), Lo Stato moderno in Europa, Laterza, Roma - Bari, 2002.

10. See N. Luhmann, Einführung in die Theorie der Gesellschaft, Carl-Auer Verlag, Heidelberg 2005, pp. 33ff.

11. For a more recent, very interesting, sociological approach that moves programmatically away from a conception of society as no-unit and that I cannot summarize here, though it partly inspired me, see B. Latour, Reassembling the Social: An Introduction to Actor-Network-Theory, Oxford Univ. Press, Oxford - New York, 2005.

12. I would like to observe that, in my reading, the substitution of the consciousness paradigm, initiated by Descartes, with the subject paradigm, as sketched by Rousseau and developed by German idealism, can be considered as an answer to a more and more complex and diversified social reality, in which the individual is clearly called upon/forced to take part to increasingly diversified forms of knowledge (Kant) and of recognition/interaction (Hegel). 
innovations/transformations. The perspective of belonging, which claims a society is constituted by human beings/subjects who are in some ways similar (homologous or uniformed) to each other, neglects that, as the socio-historical puts in relation, or rather, institutes forms of communication/interaction, at the same time distinguishes/differentiates $^{13}$ and creates the conditions for the transformation of such relationships. Among these conditions, language appears to be of primary relevance.

Although, as to the transformation of the social, which makes it historical, other conditions or rather emergences (that again cannot be classified in an evolutionary key or rather starting from a native core that unravels through them) should be taken into consideration, language (and once again I abstract from the integration of the oral language through the invention of writing ${ }^{14}$ ) is what allows:

1. the production of a shared intentionality (intersubjectively stabilized) both to the world of objects (on which one intervenes) and to co-speakers, with whom one exerts effects in the object world ${ }^{15}$;

2. thanks to its double performative-propositional structure, the opening up of the possibility not only of the "no" or of the refusal of others' proposals ${ }^{16}$, but at the same time the possibility of a revision (through language) of widespread semantic contents, of suggested syntactic-inferential connections and of relations among the co-speakers that could be established through it.

Much, or perhaps everything depends on how we consider language in its three fundamental dimensions (semantics, syntactic and pragmatic), without falling pray of abstractive-reductive visions of it. These perspectives: either exclusively illuminate an aspect of language, as in the classical semantic-referential paradigm (developed within the analytical tradition); or, as when language is considered (especially in French environment) as a system of differences; or emphasize a certain historical conformation of it (in practice, the national mother tongue), as I believe it happened throughout the predominant German line inaugurated by H.G. Hamann and J.H. Herder, that has got through M. Heidegger.

I believe that in order to overcome the idea that the meaning of our words (of conceptual terms in particular) consists in mental images (or rather, in private representations) and to defend the possibility of an intersubjective soundness of the meanings of

13. In this consists one of the greatest intuition of the Discours sur l'origine et le fondament de l'inégalité parmi les hommes (1755) by J.-J. Rousseau, deftly developed by P. Bourdieu, La distinction, Les éditions de minuit, Paris, 1979.

14. In this regard see N. Luhmann, Die Gesellschaft der Gesellschaft, Suhrkamp, Frankfurt/M, 1998, pp. 249-290; E.A. Havelock (ed.), Die Schriftrevolution im antiken Griechenland, Weinheim, VCH, 1990.

15. In this regard compare M. Tomasello, Origins of Human Communication, MIT Press, Cambridge/M., 2008.

16. How stated by P. Virno, Saggio sulla negazione. Per una antropologia linguistica, Bollati Boringhieri, Torino, 2013. 
our words (in the sense of them being amenable to learning, testing and revisability) we have to turn to a conception of language, as the second Wittgenstein would have it, as language games, in which the constitution of identical meanings for more speakers and constant meanings for the same speaker is closely tied to the success of the interaction.

If we regard the socio-historical (and so "society") as an institution of stable, branched and also reviewable interactions through communication, then we will never have so many ${ }^{17}$ unitary and distinct societies, but "multiple overlapping and intersecting sociospatial networks" ${ }^{18}$ : networks I have enlightened as language games, which branch off in a plural and no coincident way, but that can connect and develop into institutions $^{19}$ and eventually in relatively autonomous social spheres. An individual/subject, as moulded by them and at the same time able to revise them only through collaboration with others, does not take part to a society but to a plurality of networks of working interaction, which is mediated by linguistically stabilized/revisable meanings that make the constitution of the subject or the recognition of the individual never exclusively dual/horizontal (between an "I" and a "you", between ego and alter/alteri), but always dependent on concepts, categories, functions, which have arisen intersubjectively, but are then supra-subjectively stabilized and handed down.

An institution designs roles/positions and makes them durable over time. Such roles/ positions make themselves independent by their carriers and by the positions taken by these latter ones in other institutions; as a consequence among others, within institutions the interchangeability of the role of speaker/listener (typical of languages games) gets lost in favour of sedimented rules, where the moment of reciprocity is not necessarily present. The same subject or individual is involved in different institutions to different degrees and occupies positions/roles that are not necessarily determined by the position occupied in other institutions.

\footnotetext{
17. I move away from the recognition (Anerkennung) theory as originally proposed, drawing on the young Hegel, by A. Honneth, Kampf um Anerkennung, Suhrkamp, Frankfurt/M, 1992. The greatest flaw of recognition theories, mostly developed by building on Honneth, consists in the fact that recognition, even if it is inserted in diversified contexts/spheres, concerns individuals/persons, or rather, their general identity (their "self"), while the perspective I am advancing here concerns actions (interactions) and utterances (interlocutions). Nor do I fully share the more institutionalist approach, this time derived from the mature Hegel, which is outlined in Id., Das Recht der Freiheit, Suhrkamp, Berlin 2011, because of the insistence on the reciprocity ("wechselseitige Realisierung individueller Ziele", p. 101) that should qualify an institution as correct on the basis of the criterion of the authentic or full liberty that can be achieved within it. As I will suggest in more detail later on, I believe that reciprocity in equality can at most characterize only some spheres, while others, though highly useful and profitable, imply constitutive asymmetries, which, however, being variously distributed among the spheres, can be compensated in other ones by the different position that a subject occupies, or rather, by the possibilities of action/ locution allowed. This also implies a concept of freedom modulated otherwise than the one defended by Honneth.

18. M. Mann, The Sources of Social Power, vol. I, Cambridge Univ. Press, New York, 1986, p. 1.

19. In this regard see M. Croce, Che cos'è un'istituzione, Carocci, Roma, 2010.
} 
A sphere makes itself autonomous in that it creates its own language (technical, specialized), which no longer finds direct confirmation in the success of daily interaction, but articulates a knowledge whose efficacy is assured by its own interactions/institutions. I would define the latter institutions of second level (as, for instance, courts in the case of the law or rites or the institution of the Church ${ }^{20}$ in the case of so-called religion).

Despite the fact that different social theorists depicted the process, or rather, the processes of (functional) differentiation as a typical and specific feature of the modern world, others, instead, have found them also in pre-modern society and connected them specifically to the "emergence of interactions with strangers" 21 , or rather, from the point of view propounded here, to the rise of challenges, contributions, influences due to unexpected and till then distant languages games. In this way, this processes of differentiation appears no longer as a loss or a fragmentation by specialization of a previous unity, but as a way of mixing together (also remodelling) the disseminated language games, which, by overcoming their localism and particularism, are put in contact with each other beyond their geo-historical distance (that is, either in terms of space or temporal origin). Disseminated practices get not only a reflexive, self-consistent and disciplined/ disciplining self-consciousness, but at the same time connect within their own sphere, relatively autonomous, demarcated, specific, in that it functions according to categories, rules, principles, purpose-positions, that, thanks to their generality, formality, abstractness and flexibility, allow communications and interactions to overcome local contexts and idioms.

3. I now return to the fact mentioned above - namely, to the fact that the very moment the socio-historical puts in relation it also distinguishes/differentiates - to address, as a conclusion, the first term of my initial question: "power".

Communication establishes, stabilizes, intensifies and amplifies itself in institutions and spheres, as it finds confirmation in still more widened and sectorial working inter-

\footnotetext{
20. The two examples are not chosen at random, since I believe that exactly these two spheres (ius and ecclesia) have been the first that have differentiated/demarcated themselves in our West, at that time only Mediterranean, starting from the unitary political/urban horizon outlined by the classical Greek reflection. Exactly these two spheres will return under the control of a territorialized political with the formation of the system of the sovereign States. As to the ius see M. Croce, $L a$ conquista dello spazio giuridico, Edizioni Scientifiche Italiane, Napoli, 2009. As to the Christian Churches see V. Marzocchi, "Stato e democrazia, fedi e Chiese", in Fenomenologia e società, 3, 2006, pp. 25-46. For a brief historical excursus on the demarcation of further spheres in the West, beyond the law and Churches (pluralized after the civil wars of religion) see V. Marzocchi, “L'Occidente: quale differenziazione?”, in Jura Gentium, 2, 2012, pp. 1-14.

21. R. Münch, "Differentiation, Rationalisation, Interpenetration: The Emergence of Modern Society", in J.C. Alexander, P.P. Colomy (eds.), Differential Theory and Social Change. Comparative and Historical Perspectives, Columbia Univ. Press, New York, 1990, p. 448.
} 
actions, that is, in formation and organization of power, or rather, of collective powers, meant as capacity of action on the natural world (with which there is not communication) and as satisfactory coordination from the point of view of interactive individuals, at least as long as forms of coordination are experienced as deprived of practicable alternatives by them.

However, although in a derived way, collective powers imply a distributive power, as institutions and spheres that feed power, or rather, collective powers in particular, require forms of organization/coordination which: 1. outline and ascribe distinct positions, which dispose unequally of collective power; 2 . transform the used language (or its own categories, rules, principles, ways of relating) in specialized knowledge, applied and tested in specific institutions among experts, that is, into types of knowledge even more distant from their place of origin, or rather, from language games, which this types of knowledge should open and connect with each other at the same time.

Accepting, or rather, highlighting both the primarily collective/organizational nature of power and an inevitable unequal distributive power, connected to different and diversified roles/figures: if on the one hand, it avoids a zero-sum conception of power and so the coupling of power (inevitably understood as an imposition) to some sort of legitimacy/legitimation, concerning its authoritative source rather than referred to the achieved results; on the other hand, it does not imply putting aside every evaluative perspective about power/powers. In my opinion the critical-evaluative perspective, which can no longer be expressed in terms of equality, consists in what I would call the inclusive ability of collective powers, i.e. of institutions/spheres, yet in the difference of the positions designed: it resides in the ability to develop the highest degree of collective/organizational powers with the minimum imposed domination. Such an evaluative perspective does not require the use of an extrinsic criterion of justice. Such criterion or perspective, by illuminating power as the ability of someone to obtain obedience from others, places it in an exclusively intersubjective dimension, and thus neglects the organizational effectiveness in the collective results that power/powers have to produce in order to preserve themselves and then to limit them in name of a fundamental freedom and equality of all human beings. Instead, the evaluative perspective that I suggest here considers that from the point of view of the constitution/organization of a power, primarily thought of as organizing/collective, and only derivatively as distributive (indeed, I would add, only partially and limitedly divisible/redistributable, since it has an interactional and coordinative nature), every domination is also a form of dissipation, 
which prevents the exploitation or enhancement through intelligent coordination of the potentialities/ability of everyone in his essentiality and differentiated membership, that is, of the available resources ${ }^{22}$.

The perspective advanced here implies that powers are conceived in the plural and that the sphere, of which it has been especially predicated the term "power" in the modernity of the system of States (a system that still exists in the so-called age of globalization), i.e. the political sphere, is intended, in spite of its claims to prominence and monopoly, only as a sphere among others.

The differentiation in certain, relatively autonomous and mutually demarcated spheres is certainly a historical-contingent process (that is, not dependent on functions that the social must perform to reproduce itself), but it is also a result that, at least in some geo-historical sections of the world, in "our" West in particular, proved to be highly profitable for the formation of collective powers (although distributed in often strongly disproportionate ways), in the individualization of new challenges and innovative responses, besides the linking/communication of places/regions/times distant from each other and therefore in the assumption/revision of contributions elsewhere or at other time elaborated, so that one of the decisive knots of the social can be identified in the question of the so-called "interpenetration" of spheres ${ }^{23}$ without one's becoming dominant over the others, so as to monopolize the resources of sense and materials produced by the other spheres and to make its own confinements/ borders coincide with the range of influence/control/affiliation of each other. I believe it is exactly in the case of the hegemony of a sphere over the others that the cropping or rather the unification of one society by one power takes place, perhaps as happened, or the political power attempted to make happen, in the form of a national-constitutional State since the end of the eighteenth century and starting from "our" West, more exactly from western Europe.

If today another sphere, the economic one, and inside it, the financial moment seems to become hegemonic, by disrupting the boundaries of states and by imposing other ones, apparently more fluid, the perspective defended so far induces to believe

\footnotetext{
22. It seems to me that, among the great classics of the political thought, the major precursors of such a conception of power were Machiavelli and Spinoza above all, according to whom power (in these cases political) is always potentiation, in order to affirm, to sustain and to develop itself.

23. It is this, in my opinion, the core question circumvented and eventually evaded by N. Luhmann, only partially faced by his former student G. Teubner, in particular about the relation of the juridical sphere to the others (see G. Teubner, Recht als autopoietisches System, Suhrkamp, Frankfurt/M, 1989; Id., "Globale Zivilverfassungen: Alternativen zur staatszentrierten Verfassungstheorie", in Zeitschrift für ausländisches öffentliches Recht und Völkerrecht, 63, 2003, pp. 1-28). Such question is made instead central by R. Münch, Die Struktur der Moderne, Suhrkamp, Frankfurt/M 1984.
} 
that the remedy cannot consist in a re-centralization of the social on the political or better on the political-juridical, the way that it has taken shape since the two great revolutions of the eighteenth century (the American and the French ones), however de-nationalized, democratized and globally extended in a cosmopolitan optic, but in the following double direction: on the one hand, the political would acquire the character of an artificial place of equality and discursive confrontation among all interactive individuals, beyond their previous and various belongings, in order to give voice and visibility also to the "without a part"24; on the other hand, it would drop the temptation to outline, to give a shape and equal norms to one society, and would aim to make com-possible, without mutual colonization, institutions and spheres (i.e. forms of relation/interaction) that are already confirmed or emerging, in order to favour a wider and multifaceted sociality.

24. See J. Rancière, La Mésentente, Éditions Galilée, Paris, 1995. 